\title{
Yerel Halkın Bölge Turizmine Bakış Açılarının ve Farkındalıklarının Belirlenmesi Üzerine Çankırı'da Bir Araştırma
}

\section{A Research in Çankırı on Determination of Perspectives and Awareness of Local People on Regional Tourism}

\author{
Dr. Öğr. Üyesi Yakup ÖZTÜRK \\ Çankırı Karatekin Üniversitesi
}

Ilgaz Turizm Ve Otelcilik Yüksekokulu, Çankırı, Türkiye

E-posta: ozturkykp@gmail.com

Öz

Bu çalışmada Çankırı ilinin turistik arz değerleri ile halkın bölge turizmine yönelik bakış açıları ve farkındalıklarının belirlenmesi amaçlanmaktadır. Bununla birlikte yerel halkın ilin turizm potansiyeline yönelik bilgi düzeyi, Çankırı'da hangi turizm türlerinin uygulanabileceği ve Çankırı turizminin sorunlarına yönelik görüşleri araştırılan diğer konulardır. Çankırı Karatekin Üniversitesi Etik Kurul'unun 30.04.2019 tarih ve 116 numaralı izin kararıyla hazırlanmış olan araştırma kapsamında verilerin toplanması için anket çalışması yapılmış, toplanan anketlerin 407 tanesi analize tabi tutulmuştur. Araştırmada elde edilen bulgular, yerel halkın çoğunlukla şehir merkezi ve yakınlarındaki turizm alanlarını ziyaret ettiklerine, Çankırı turizmine yönelik görüşlerin Çankırı'nın doğal ve kültürel zenginlikleri konusundaki bilgi düzeyi ve ikamet süresi değişkenlerine göre farklılaştığına işaret etmektedir. Ayrıca katılımcılar, Çankırı'da mağara ve kış turizmine ağırlık verilmesi gerektiğini ifade etmişlerdir.

Anahtar Kelimeler: Çankırı, Turizm potansiyeli, Turizme yönelik farkındalık, Yerel halk

\section{Abstract}

In this study, it is aimed to determine the tourism supply values of Çankırı province and the perspectives and awareness of the people towards the regional tourism. In addition, the knowledge of the local people about the tourism potential of the region, which types of tourism can be applied in Çankırı and their views on the problems of Çankırı tourism are other topics that are investigated. In order to collect data, questionnaire technique, which is one of the quantitative research methods, was used and the analyzes were performed in the light of the data obtained from 407 questionnaires. The results of the study indicate that the local people mostly visit the tourism centers in the city center and nearby and that the opinions about Çankırı tourism vary according to the knowledge level and residence time of Çankırı. In addition, the participants stated that cave and winter tourism should be emphasized in Çankırı.

Key Words: Çankırı, Tourism potential, Awareness of tourism, The local community 


\section{Giriş}

Çok boyutlu bir kavram olan turizm, insanların sürekli ikamet ettikleri yer dışına yaptıkları ziyaretler ve gittikleri yerlerdeki geçici konaklamalarından kaynaklanan gereksinimlerinin karşılanmasına yönelik faaliyetler bütünüdür (Kahraman ve Türkay, 2014:1). Her yıl milyonlarca insanın ulusal ve/veya uluslararası hareketliliğe dâhil olduğu küresel bir endüstri olan turizmin ülke ekonomilerindeki önemi otoriteler tarafından kabul edilmektedir (Lee, Li ve Kim, 2007:91). Günümüzde dünyadaki ekonomik kalkınma programlarının önemli bir bileşeni haline gelen turizm (Harrill, 2004:251); ulusal ve uluslararası platformda sadece ekonomik bir olgu olmanın ötesinde sosyal ve kültürel yönleri ile de toplumsal yapıyı etkileyen (Berber, 2003:205), çok boyutlu bir süreç olarak değerlendirilmektedir.

Bir destinasyonda turizmin gelişmesi ile yerleşik halk kısa vadede, pek çok toplulukta olduğu gibi, istihdam oluşturma, gelir yaratma ve bölge alt yapısının gelişmesi gibi olumlu etkilerinden dolayı turizme olumlu yaklaşım sergilerken, sosyokültürel ve çevresel boyutundaki muhtemel olumsuz etkileri nedeniyle turizmi endişe verici bir olgu olarak algılayabilmektedir. Literatürde yer alan pek çok çalışmada yerel halkın (Meriç ve Erten, 2020; Ercan, 2019; Sert, 2019; Hançer ve Mancı, 2017; Mansuroğlu, 2006) ve yerel yöneticilerin (Akyol, Zengin, Akkaşoğlu ve Ulema, 2020), turizmin etkileri hakkındaki algılarına odaklanılmıştır. Bu çalışmalar, yerel paydaşların turizm gelişimine ilişkin algılarının anlaşılmasını sağlayarak, uygulayıcılara ve politika geliştiricilere daha iyi stratejiler geliştirilmesi için yol gösterici olmuştur (Chen, 2001:235).

Turizm gelişimi bölgede yaşayan yerleşik nüfusun davranışlarıyla yakından ilgilidir (Solmaz, 2014:101). Araştırmacılar yerel halkın bölge turizmine yönelik algılarının ziyaretçi memnuniyetinde önemli bir faktör olduğunu ve bu nedenle turizm endüstrisinin başarısı için hayati önem taşıdığını ifade etmişlerdir (Andriotis ve Vaughan, 2003:172). Literatürde yer alan çalışmalar, ev sahibi destinasyonun yerel sakinlerinin turizm gelişiminin odak noktasında olduğunu, başarılı ve sürdürülebilir bir turizm gelişiminde yerel halkın vereceği desteğinin kritik bir öneme sahip olduğunu göstermektedir (Öztürk, Özer ve Çaliskan, 2015; Sandal ve Karademir, 2016; Boğan ve Sarışık, 2016; Gündüz, 2018). Bölge sakinlerinin turizm gelişimi ve etkileri konusundaki algılarının bilinmesi, planlamacıların uygun politikalar geliştirerek halkın endişelerinin giderilmesine yardımcı olabilecektir.

Nunkoo ve Ramkissoon (2007:143) sürdürülebilir turizm gelişimi için yerel halkın karar süreçlerinde katıımının arttırımasının önemli olduğunu ifade etmişlerdir. Turizm gelişiminin sağlıklı ve verimli yönetilebilmesi tüm çevre unsurlarının ve yerel halkın her açıdan turizme hazırlanması ve turizm faaliyetlerine katılımının sağlanması önemli bir konudur (Şentürk ve Toprak, 2011:325). Turizm planlamalarının yerel halk merkezli oluşturulması ya da stratejilerin yerel halkın görüşlerini de dikkate alacak şekilde oluşturulması sürdürülebilir turizm için önemli bir unsur olarak değerlendirilmektedir (Boğan ve Sarışık, 2016:326). Ayrıca yerel halkın turizme yönelik tutumları belirli zaman dilimlerinde araştırılmalı, sürdürülebilir turizm için planlanan turizmin gelişme şekli, ölçeği ve konumu ile ilgili olarak yöre toplumunun kabulü sağlanmalıdır (Özdemir ve Kervankıran, 2011:5).

Bölge halkının turizm gelişimine ilişkin algılarının ve tutumlarının tespit edilmesi, destinasyona yönelik uygulanacak turizm gelişim politikalarının başarısı ve sürdürülebilirliği açısından önem teşkil etmektedir. Yerel toplumun değerleri ve beklentilerinin dikkate alınmadığı ve kararların dışında tutulduğu, salt ekonomik temele 
dayalı bir turizm gelişiminde uzun vadede başarı sağlanamayacaktır (Hançer ve Mancı, 2017:71).

Yerel halkın turizmin etkilerine yönelik tutumları kapsamlı olarak araştırılan bir konudur. Hem ulusal hem de uluslararası ölçekte gelir getirici bir faaliyet olduğu değerlendirilen turizmin gelişimi için yerel halkın desteğinin sağlanmasının şart olduğu konusunda literatürde fikir birliği (Kuvan ve Akan, 2005; Bestard ve Nadal, 2007; Nunkoo ve Ramkissoon, 2011) olduğu söylenebilir. Daha önce hazırlanmış olan çalışmalar (Alaeddinoğlu, 2008; Öner ve Aydoğdu, 2019; Çiçek ve Sarı, 2018; Güneş ve Alagöz, 2018; Oğuzbalaban, 2017; Sandal ve Karademir, 2016) turizm gelişiminin genel hedeflerine ulaşmasında yerel halkın önemli bir rol oynadığına ve yerel halkın katıımının sağlanmasının gerekliliğine dikkat çekmektedir (Choi ve Sarıkaya, 2005:391). Kentsel destinasyonlarda turizm potansiyelinin değerlendiril(ebil)mesi kadar, yerel halkın turizm olgusuna yaklaşımı ve farkındalığının belirlenmesi de önem arz etmektedir. Turizm değerlerinin korunması ve gelecek nesillere aktarılabilmesi için, bireylerin turizm farkındalığına sahip olması gerekmektedir.

Bu çalışmada Çankırı ilinde turizme kaynak oluşturan tabiat turizmi maksatı kullanılan ve koruma statülü alanlar, tarih ve kültür alanları, inanç turizmi alanları ve seçkin özellikli diğer sahalar konusunda bölgede yaşayan yerel halkın bilgi düzeyleri ve ziyaret özellikleri tespit edilerek, bölgede geliştirilmesi gereken turizm çeşitlerine yönelik görüşleri araştırılmıştır. Ayrıca yerel halkın Çankırı'nın turizm potansiyeli ve kullanımı ile geliştirilmesine yönelik görüşleri analiz edilerek halkın turizme yönelik bakış açısının tespit edilmesi amaçlanmaktadır. Çalışmada istatistiki verilerin ve destinasyona ilişkin bilgilerin tasnifi ile hem ilgili araştırmacıların hem de sektör paydaşlarının bilgilendirilmesi hedeflenmektedir. Böylece halkın turizm planlamaları için bilgi sağlayarak yörenin doğal ve kültürel özelliklerine uygun turizm anlayışının geliştirilebileceği düşünülmüştür.

\section{2. Çalışma Alanının Genel Özellikleri ve Turizm Potansiyeli}

Çankırı ismi, klasik dönemden Luvi devrine kadar uzanan, antik bir Luvi ismi olan "Gangra" kelimesinin halk etimolojisine uygun olarak "çan" ve "kırık" kelimeleri kullanılarak Çankırı haline dönüşmüş halidir (İbiş, 2014:10). İç Anadolu ile Batı Karadeniz Bölgesi arasında geçiş konumunda bulunan, merkez ilçeyle birlikte toplam 12 ilçeden oluşan ve yüzölçümü $7490 \mathrm{~km}^{2}$ olan ilin nüfusu 216.362'dir (Çankırı Valiliği, 2019).

Doğal güzelliklerinin yanı sıra önemli bir tarihi geçmişe de sahip olan, İnandıktepe ve Çorakyerler höyükleri ile M.Ö. 2000 yılına kadar ışık tutan Çankırı; Hititler döneminden itibaren Romalılar, Selçuklular, Danişmentliler, Candaroğulları ve Osmanlılar tarafından yerleşim yeri olarak kullanılmıştır (Tuna, 2010:232). Çankırı; doğal, tarihi ve kültürel değerleri ile Türkiye'nin turizm potansiyeli açısından önemli destinasyonlarından biridir. Çankırı'nın önemli kültürel ve doğal çekim unsurları arasında Taş Mescit, Emir Karatekin Türbesi, Çankırı Kalesi, Saat Kulesi, Ilgaz Dağı Milli Parkı ve Kadın Çayırı Tabiat Parkı ve Yaran Kültürü sıralanabilir.

Çankırı kent imajının oluşumunda tarihi ve dini yapılar önemli yer tutmaktadır. Taş Mescit Çankırı'da Selçuklular Dönemi'nden kalma en önemli yapıdır. Cemaleddin Ferruh Şifahanesi ve Darülhadisi olarak birbirine bitişik inşa edilen bu iki yapı ilgi odağı niteliğindedir (www.kulturportali.gov.tr). Bu iki yapıdan, Dârüşşifa zamanla yıkılmış Dârülhadis ise günümüze kadar sağlam kalmıştır. Ancak Dârüşşifa'nın kitabesindeki figür önemli olup, bir kadeh etrafına dolanmış iki yılanın resmedildiği ilk bulgudur. 
Günümüzde "Tıp Sembolü" olarak da kullanılan bu sembol bu anlamda önem taşımaktadır (Bakır, 2018:20). Mimar Sinan dönemi yapılarından olan ve Kanuni Sultan Süleyman'ın emri ile yaptırılmış olan Ulu Camii ve mimari olarak önemli bir özelliği olmamakla birlikte, Horasan Erenlerinden olan Hacı Murad-ı Veli'nin Türbe'si olması sebebiyle, Hacı Murad-ı Veli Camii ve Türbesi önem arz etmekte ve çok sayıda ziyaretçi çekmektedir (www.kulturportali.gov.tr). Şehre hâkim bir tepe üzerine kurulmuş olan yaklaşık 150 m yüksekliğindeki Çankırı Kalesi'nden günümüze sadece kale kapısı yönündeki duvar kalıntısı ulaşmıştır. İçerisinde Roma döneminden kalan kaya mezarları, iskân kalıntıları ve pişmiş toprak kap parçaları ile Çankırı fatihi olarak bilinen Karatekin Bey'in türbesi bulunmaktadır (Türkan, 2017:411). Türbe Danişmentlilerden günümüze ulaşabilen tek eseridir (Tuna, 2010: 232).

Çankırı, merkez ilçeye $20 \mathrm{~km}$ uzaklıkta bulunan ve Hititler döneminden günümüze yaklaşık 5.000 yıldır tuz çıkarılan, Türkiye'nin en büyük kaya tuzu rezervine sahip Tuz Mağarası'na ev sahipliği yapmaktadır. Mağarada tuz üretiminin tamamlandığı galerilerin turizme kazandıııması amacıyla, Çankırı Valiliği tarafından hazırlanan ve Kuzey Anadolu Kalkınma Ajansı'na sunulan "Çankırı Kaya Tuzu Mağarasının Turizme Kazandırıması Projesi" desteklenmeye hak kazanmıştır (Doğdubay ve Göker, 2018:250). Çankırı ilinin önemli turistik arz değerleri Tablo 1'de yer almaktadır.

\section{Tablo 1: Çankırı’nın Turistik Arz Değerleri}

Milli Park ve Benzeri Sahalar

Seçkin Özellikli Diğer Sahalar

İnanç Turizmi Alanları

Tarih ve Kültür Alanları
Ilgaz Dağı Milli Parkı, Hazım Dağlı Tabiat Parkı, Kadın Çayırı Tabiat Parkı, Kenbağ Tabiat Parkı

Kırkpınar Yaylası, Mülayim Yaylası, Büyük Yayla, Küçük Yayla, Bıldırcın Yaylası, Düvenlik Yaylası, Çavundur Kaplıcası, Bülbül Pınarı, Alpsarı Göleti, Çankırı Tuz Mağarası

Emir Karatekin Bey Türbesi, Hacı Murad-ı Veli Türbe ve Camii, Hoş İslamlar Türbesi, Pir-i Sani Türbesi, Fethiye Türbesi, Büyük Camii, Şeyh Mehdi Türbesi

Beşdut Kaya Mezarları, İndağı Kaya Mezarları, Çankırı Kalesi, Saat Kulesi, Taş Mescit, Sakaeli Kaya Mezarları ve Peri Bacası Oluşumları

Kaynak: Orman ve Su İşleri Bakanlığı, 2019; Kuter, 2007

\section{Yöntem}

Bu çalışmanın temel amacı, Çankırı'da ikamet eden bireylerin Çankırı'nın turizm potansiyeli-kullanımı ile geliştirilmesine yönelik görüşlerinin ve farkındalığının belirlenmeye çalışılmasıdır. Çalışma öncesinde 30.04.2019 tarihli toplantı ve 116 nolu kararı ile Çankırı Karatekin Üniversitesi Etik Kurul'undan izin alınmıştır. Veri toplamak amacıyla nicel araştırma yöntemlerinden anket tekniğinin kullanıldığı bu araştırmanın ana kütlesini Çankırı'da ikamet eden 18-61 ve üzeri yaş arası katılımcılar oluşturmaktadır. Çalışmanın evreninin tamamına ulaşılmasının mümkün olmamasından dolayı örneklem belirleme yoluna gidilmiştir. Ural ve Kılıç'ın (2013:47) belirtmiş oldukları örneklem büyüklüğünden hareketle örneklem sayısı 384 olarak belirlenmiştir. Araştırma kapsamında 6-31 Mayıs 2019 tarihleri arasında 420 katılımcıya anket uygulanmış, kullanılabilir nitelikte olan 407 adedi değerlendirmeye alınmıştır. 
İki bölümden oluşan anket formunun birinci bölümünde katılımcıların demografik özelliklerini belirlemeye yönelik ifadeler, Çankırı'nın doğal ve kültürel zenginlikleri konusunda bilgi düzeylerine yönelik ifadeler ve Çankırı'nın turistik arz kapasitesi ve katılımcıların ziyaret yapılarına yönelik ifadeler yer almaktadır. Anketin ikinci bölümünde ise, Doğan ve Üngüren (2012) tarafından geliştirilmiş olan ölçek kullanılmıştır. Bu bölüm yerel halkın Çankırı ilinin turizm potansiyeli-kullanımı ile geliştirilmesine yönelik görüşlerinin tespit edilmesini amaçlayan "Çankırı Turizminin Sorunları", "Turizmin Çankırı'ya Sağlayacağı Katkılar", "Turizm Geliştirme Stratejileri", "Çankırı'nın Turizm Potansiyeli ve Kullanımı" ve "Festivaller ve Çankırı" olarak belirlenen 5 alt boyut ve 21 önermeden oluşmaktadır. Ölçekte $5^{\prime} l i$ Likert derecelendirme sistemi kullanılmıştır.

Ölçeğin yapı geçerliliğini test etmek amacıyla AMOS programıyla ölçek için birinci düzey çok faktörlü doğrulayıcı faktör analizi yapılmıştır. Ölçeğin geçerliliğini test etmek için oluşturulan ölçüm modelinin ürettiği uyum değerleri kabul edilebilir sınırlar içinde olmadığı için AMOS programının önerdiği modifikasyonlar yapılmış ve toplamda 4 ifade ölçekten çıkartılmıştır.

Tablo 2: Ölçeğin Uyum Değerleri

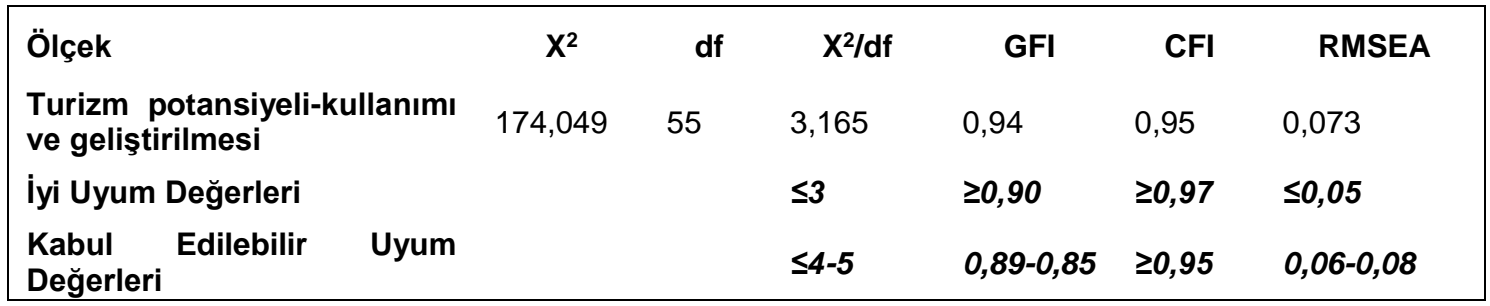

Tablo 2'de yer alan ölçek uyum değerleri kabul edilebilir sınırlar içinde olduğundan ölçeğin 5 faktörlü yapısı doğrulanmıştır. Bu faktörler; "Çankırı Turizminin Sorunları", "Turizmin Çankırı'ya Sağlayacağı Katkılar", "Turizm Geliştirme Stratejileri”, "Çankırı'nın Turizm Potansiyeli ve Kullanımı" ve "Festivaller ve Çankırı" olarak belirlenmiştir.

Araştırmanın güvenirliği, bir ölçeğin ölçüm sonuçlarının farklı ana kütlelerde veya aynı ana kütleye ait farklı ana kütlelerde aynı sonucu vermesi durumudur (Şencan, 2005:11). Bir araştırmada güvenirliği ölçmek için en çok kullanılan istatistik ise Cronbach's Alpha katsayısıdır. Cronbach's Alpha değerinin 0.70 ve üstü olması ölçme aracının güvenirliği için yeterli görülmekte olup bu değeri karşılayan ölçme aracının güvenilir olduğu kabul edilmektedir (Dilekçi ve Sezgin Nartgün, 2020:455).

Tablo 3: Verilerin Dağılımı ve Güvenirliğine İlişkin Bulgular

\begin{tabular}{|c|c|c|c|c|}
\hline Faktörler / Maddeler & $\begin{array}{l}\text { Faktör } \\
\text { Yükü }\end{array}$ & Çarpıklık & Basıklık & ALFA \\
\hline Çankırı Turizminin Sorunları & DFA & Statistic & Statistic & \\
\hline Turizm açısından önemli alt yapı sorunları vardır & 0,84 &,- 668 &,- 911 & \\
\hline $\begin{array}{l}\text { Çankırı / Çankırılılar turizme gereken önemi } \\
\text { göstermemektedir. }\end{array}$ & 0,87 &,- 862 &,- 490 & ,846 \\
\hline $\begin{array}{l}\text { Turizmin gelişmesine yönelik ilin temel kuruluş ve } \\
\text { birimleri arasında yeterli ve etkin bir dayanışma, } \\
\text { işbirliği, iletişim ve koordinasyon yoktur. }\end{array}$ & 0,71 &,- 554 &,- 790 & \\
\hline
\end{tabular}


Tablo 3'ün devamı

Turizmin Çankırı'ya Sağlayacağı Katkılar

Turizmin Çankırı ekonomisine büyük katkı yapacağını düşünüyorum.

Turizmin Çankıı'da istihdam olanaklarını arttıracağını düşünüyorum.

Çankırı'nın gelişiminde turizm lokomotif rol oynayabilir.

Turizm Geliştirme Stratejileri

Turizm sadece "Turizm İ Müdürlüğünün" çalışmalarıyla başarılabilecek bir iş değildir.

Turizmde başarı için yerel halk ve tüm kesimlerin katılımı gereklidir.

Turizmin gelişmesi için turizm yatırımlarının arttırılmasına öncelik verilmelidir.

Çankırı'nın Turizm Potansiyeli ve Kullanımı

Çankırı zengin bir turizm potansiyeline sahiptir.

Çankırı sahip olduğu turizm potansiyelini yeterince değerlendirememektedir.

Festivaller ve Çankırı

Bir ilin tanıtımı ve gelişiminde festivaller önemli rol oynamaktadır.

Düzenlenen festivallerin Çankırı ekonomisine önemli katkılar sağladığına inanıyorum.

$0,73 \quad-862 \quad-, 361$

$0,78 \quad-, 813 \quad-, 386$

$0,74 \quad-, 442 \quad-, 940$

$0,77 \quad-, 602 \quad-, 724$

$0,82 \quad-, 934 \quad-, 023$

, 855

$0,85 \quad-, 903 \quad-, 131$

$0,59 \quad-, 504 \quad-, 606$

$0,77 \quad-, 740 \quad-, 130$

0,76 - -,536 $\quad-, 948$

Toplam Açıklanan Varyans: 76,603 Kaiser-Meyer-Olkin Örneklem Yeterliliği Ölçüsü: ,887 Bartlett Küresellik Testi: Ki Kare: 2603,843 p değeri: 0,000

Verilerin normal dağılıma sahip olup olmadığını analiz etmek için "Çarpıklık ve Basıklık" değerleri incelenmiştir. Bu bağlamda Skewness ve Kurtosis değerlerinin (-+) 1 aralığında olması parametrik testlerin yapılabileceğini göstermektedir (Deniz vd., 2014:309). Tabachnik ve Fidell'e (2013:80) göre de çarpıklık ve basıklığın $-1,5$ ve $+1,5$ aralığında olması ölçeğin normal dağılım göstermiş olduğunu göstermektedir. Yapılan analizlerde ölçekte yer alan ifadelerin çarpıklık ve basıklık değerlerinin -1,5 ile 1,5 aralığında olduğu ve ilgili değişkenlere ait verilerin normal dağılım gösterdiği tespit edilmiştir. Araştırma kapsamında katılımcılardan elde edilen verilerin normal dağılım göstermesi nedeniyle parametrik analizlerden faydalanılmıştır.

Demografik özelliklere ilişkin veriler için frekans analizi, yerel halkın turizm algıları ile cinsiyet, medeni durum ve doğum yeri değişkenleri arasındaki farklııkları belirlemek amacıyla t-Testi testi yapılmıştır. Katılımcıların Çankırı'da ikamet sürelerine göre Çankırı turizmi algıları ile ilin doğal ve kültürel zenginlikleri konusundaki bilgi düzeyleri ile Çankırı turizmine yönelik görüşleri arasında anlamlı farklıığın olup olmadığının tespitine yönelik One-Way Anova Analizi yapılmıştır.

Literatürde yerel halkın turizmi nasıl algıladığı (Doğan ve Üngüren, 2012; Solmaz, 2014; Toprak, 2015; Gündüz, 2018; Boğan ve Sarışık, 2016), bölge turizminin gelişmesi için nelerin yapılması gerektiği (Özdemir ve Kervankıran, 2011), turizmin gelişiminin halk için ne ifade ettiği (Sandal ve Karademir, 2016), yerel halkın turizme ne kadar açık olduğu ve turizmi ne oranda desteklediğinin belirlenmesine (Alaeddinoğlu, 2007) yönelik çalışmaların ortak bulgusu yerel halkın genel olarak turizmin ildeki gelişim sürecine olumlu yaklaştığı ve turizm yatıımlarının artması gerektiğini düşündüğüdür. Çalışmanın amaçları doğrultusunda geliştirilen hipotezler şu şekildedir:

H1. Katılımcıların demografik özellikleri ve Çankırı turizmine yönelik görüşleri arasında bir farklılık vardır. 
H1a. Katılımcıların cinsiyetleri ile Çankırı turizmine yönelik görüşleri arasında bir farklılık vardır.

H1b. Katıımcıların medeni durumları ile Çankırı turizmine yönelik görüşleri arasında bir farklılık vardır.

H1c. Katılımcıların doğum yerleri ile Çankırı turizmine yönelik görüşleri arasında bir farklıık vardır.

H2. Katıımcıların Çankırı'daki ikamet süreleri ile Çankırı turizmine yönelik görüşleri arasında bir farklılık vardır.

H2a. Katıımcıların Çankırı'daki ikamet süreleri ile Çankırı turizminin sorunları algıları arasında bir farklılık vardır.

H2b. Katılımcıların Çankırı'daki ikamet süreleri ile turizmin Çankırı'ya sağlayacağı katkılar algıları arasında bir farklılık vardır.

H2c. Katıımcıların Çankırı'daki ikamet süreleri ile turizm geliştirme stratejileri algıları arasında bir farklıık vardır.

H2d. Katılımcıların Çankırı'daki ikamet süreleri ile Çankırı'nın turizm potansiyeli ve kullanımı algıları arasında bir farklıık vardır.

H2e. Katılımcıların Çankırı'daki ikamet süreleri ile festivaller ve Çankırı algıları arasında bir farklılık vardır.

H3. Katılımcıların Çankırı'nın doğal ve kültürel zenginlikleri konusundaki bilgi düzeyleri ile Çankırı turizmine yönelik görüşleri arasında bir farklılık vardır.

H3a. Katılımcıların Çankırı'nın doğal ve kültürel zenginlikleri konusundaki bilgi düzeyleri ile Çankırı turizminin sorunları algıları arasında bir farklıık vardır.

H3b. Katıımcıların Çankırı'nın doğal ve kültürel zenginlikleri konusundaki bilgi düzeyleri ile turizmin Çankırı'ya sağlayacağı katkılar algıları arasında bir farklılık vardır.

H3c. Katılımcıların Çankırı'nın doğal ve kültürel zenginlikleri konusundaki bilgi düzeyleri ile turizm geliştirme stratejileri algıları arasında bir farklıık vardır.

H3d. Katılımcıların Çankırı'nın doğal ve kültürel zenginlikleri konusundaki bilgi düzeyleri ile Çankırı'nın turizm potansiyeli ve kullanımı algıları arasında bir farkııık vardır.

H3e. Katılımcıların Çankırı'nın doğal ve kültürel zenginlikleri konusundaki bilgi düzeyleri ile festivaller ve Çankırı algıları arasında bir farklıık vardır.

\section{Bulgular}

Tablo 4'te yer alan bulgulara göre katılımcıların \%55,5'inin kadın, \%44,5'inin erkek olduğu görülmektedir. Medeni durumları açısından ise katılımcıların \%52,8'inin bekâr, \%47,2'sinin evli olduğu tespit edilmiştir. Katılımcıların \%30,5'inin 25-34 yaş grubunda oldukları ve onları \%30,2 ila 18-24 yaş grubunda yer alanların izlediği görülmektedir. 61 yaş ve üzerinde olanların oranı ise \%2,2'dir. Araştırmaya katılanların \%33,2'si işçi, 
\%24,6'sı kamu çalışanı ve \%2,9'u ise diğer farklı meslek gruplarında yer almaktadır. Katılımcıların \%63,1'inin Çankırı doğumlu olduğu, \%42,3'ünün de 18 ve üzeri yıldan daha fazla bir süredir Çankırı'da ikamet ettiği tespit edilmiştir. Katılımcıların $\% 36,4$ 'ünün lise düzeyinde eğitim seviyesinde oldukları ve \%36,1'inin aylık 2021-3000 TL gelire sahip oldukları tespit edilmiştir.

Tablo 4: Katılımcıların demografik özelliklerine göre dağııımı (n:407)

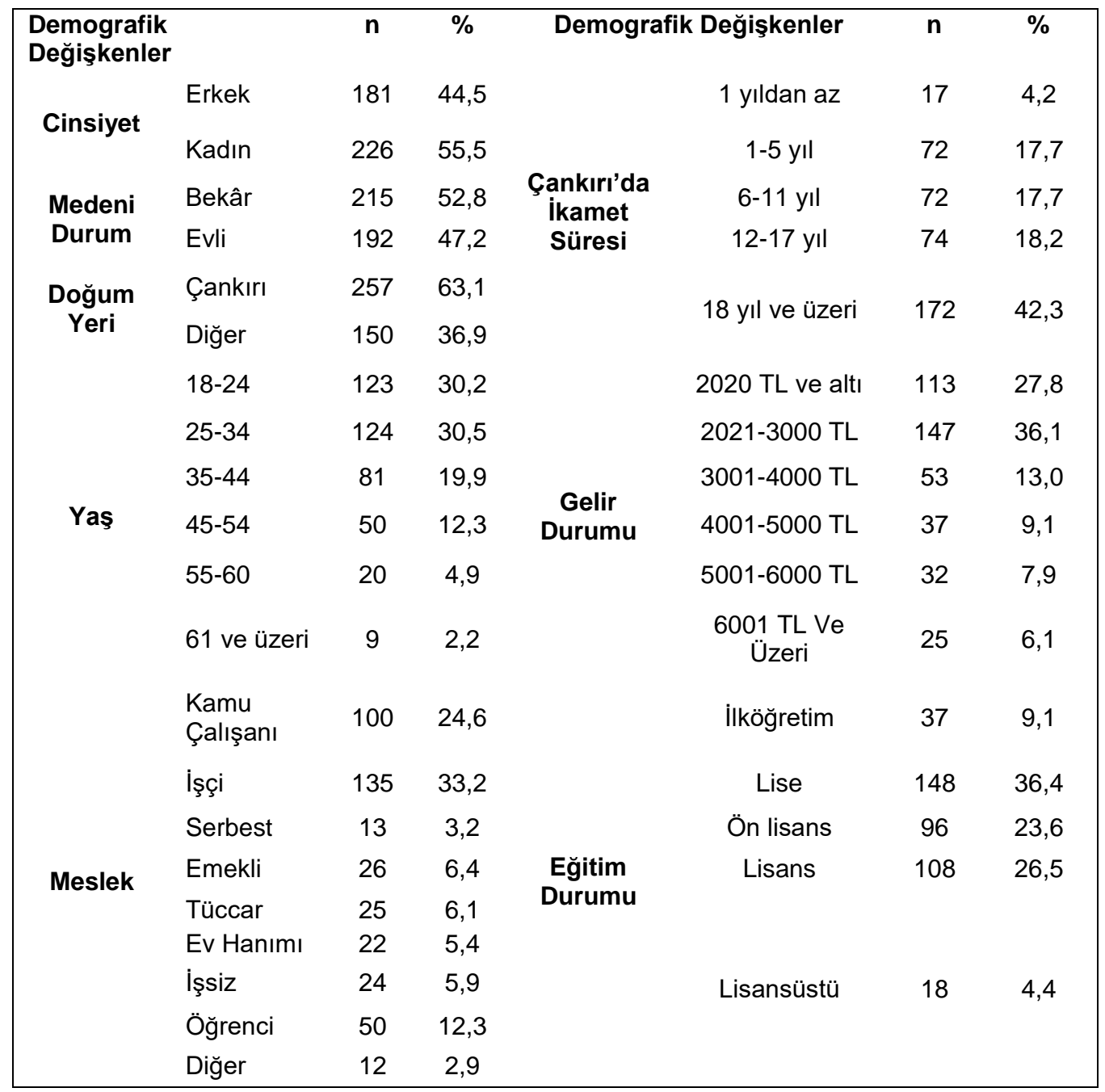

Bir destinasyonun daha fazla turist çekebilmesi için intimalleri ortaya koymada önemli bir konu olan turizm potansiyeli sınırlıysa başarılı bir turizm girişimini başlatmak imkânı olmayacaktır. Çankırı alternatif turizm alanlarına sahip olmasıyla yüksek turizm potansiyeline sahiptir. Tablo 5 'te yer alan araştırma bulgularına göre katılımcılar tarafından en fazla ziyaret edilen alanlar; Çankırı Kalesi, Taş Mescit, Çankırı Tuz Mağarası, Ilgaz Dağı Milli Parkı, Alpsarı Göleti ve Emir Karatekin Bey Türbesi'dir. 
Tablo 5: Katılımcıların Çankırı'daki Turizm Alanlarını Ziyaret Yapılarına İlişkin Bulgular

\begin{tabular}{|c|c|c|c|c|c|}
\hline \multicolumn{2}{|c|}{ Çankırı'daki Turizm Alanlarından hangilerini ziyaret ettiniz? } & $\begin{array}{c}\text { Evet } \\
\text { (n) }\end{array}$ & $\begin{array}{c}\text { Hayır } \\
\text { (n) }\end{array}$ & $\begin{array}{c}\text { Evet } \\
\text { (\%) }\end{array}$ & $\begin{array}{c}\text { Hayır } \\
(\%)\end{array}$ \\
\hline \multirow{4}{*}{$\begin{array}{l}\text { Tabiat turizmi maksatlı } \\
\text { kullanılan ve koruma } \\
\text { statülü alanlar }\end{array}$} & Ilgaz Dağı Milli Parkı & 298 & 109 & 73,2 & 26,8 \\
\hline & Hazım Dağıı Tabiat Parkı & 119 & 288 & 29,2 & 70,8 \\
\hline & Kenbağ Tabiat Parkı & 175 & 232 & 43 & 57 \\
\hline & Kadın Çayırı Tabiat Parkı & 190 & 217 & 46,7 & 53,3 \\
\hline \multirow{7}{*}{ Tarih ve Kültür alanları } & Beşdut Kaya Mezarları & 61 & 346 & 15 & 85 \\
\hline & İndağı Kaya Mezarları & 126 & 281 & 31 & 69 \\
\hline & Çankırı Kalesi & 343 & 64 & 84,3 & 15,7 \\
\hline & Saat Kulesi & 201 & 206 & 49,4 & 50,6 \\
\hline & Taş Mescit & 313 & 94 & 76,9 & 23,1 \\
\hline & Büyük Camii & 271 & 136 & 66,6 & 33,4 \\
\hline & $\begin{array}{c}\text { Sakaeli Kaya Mezarları ve Peri } \\
\text { Bacası Oluşumları }\end{array}$ & 50 & 357 & 12,3 & 87,7 \\
\hline \multirow{5}{*}{ İnanç Turizmi alanları } & Emir Karatekin Bey Türbesi & 290 & 117 & 71,3 & 28,7 \\
\hline & Hacı Murad-ı Veli Türbe ve Camii & 236 & 171 & 58 & 42 \\
\hline & Hoş İslamlar Türbesi & 84 & 323 & 20,6 & 79,4 \\
\hline & Pir-i Sani Türbesi & 44 & 363 & 10,8 & 89,2 \\
\hline & Fethiye Türbesi & 38 & 369 & 9,3 & 90,7 \\
\hline \multirow{11}{*}{$\begin{array}{c}\text { Seçkin Özellikli Diğer } \\
\text { Sahalar }\end{array}$} & Şeyh Mehdi Türbesi & 49 & 358 & 12 & 88 \\
\hline & Kırkpınar Yaylası & 178 & 229 & 43,7 & 56,3 \\
\hline & Mülayim Yaylası & 52 & 355 & 12,8 & 87,2 \\
\hline & Büyük Yayla & 109 & 298 & 26,8 & 73,2 \\
\hline & Küçük Yayla & 86 & 321 & 21,1 & 78,9 \\
\hline & Bıldırcın Yaylası & 38 & 369 & 9,3 & 90,7 \\
\hline & Düvenlik Yaylası & 34 & 373 & 8,4 & 91,6 \\
\hline & Çavundur Kaplıcası & 154 & 253 & 37,8 & 62,2 \\
\hline & Bülbül Pınarı & 141 & 266 & 34,6 & 65,4 \\
\hline & Alpsarı Göleti & 295 & 112 & 72,5 & 27,5 \\
\hline & Çankırı Tuz Mağarası & 299 & 108 & 73,5 & 26,5 \\
\hline
\end{tabular}

Tablo 5'te yer alan sonuçlara göre katılımcıların Çankırı'daki turizm alanlarını ziyaret yapıları incelendiğinde en az ziyaret edilen alanın seçkin özellikli diğer sahalardan Düvenlik Yaylası olduğu görülmektedir. 
Tablo 6: Yerel Halkın Çankırı Turizmi Algısına Yönelik t-Testi

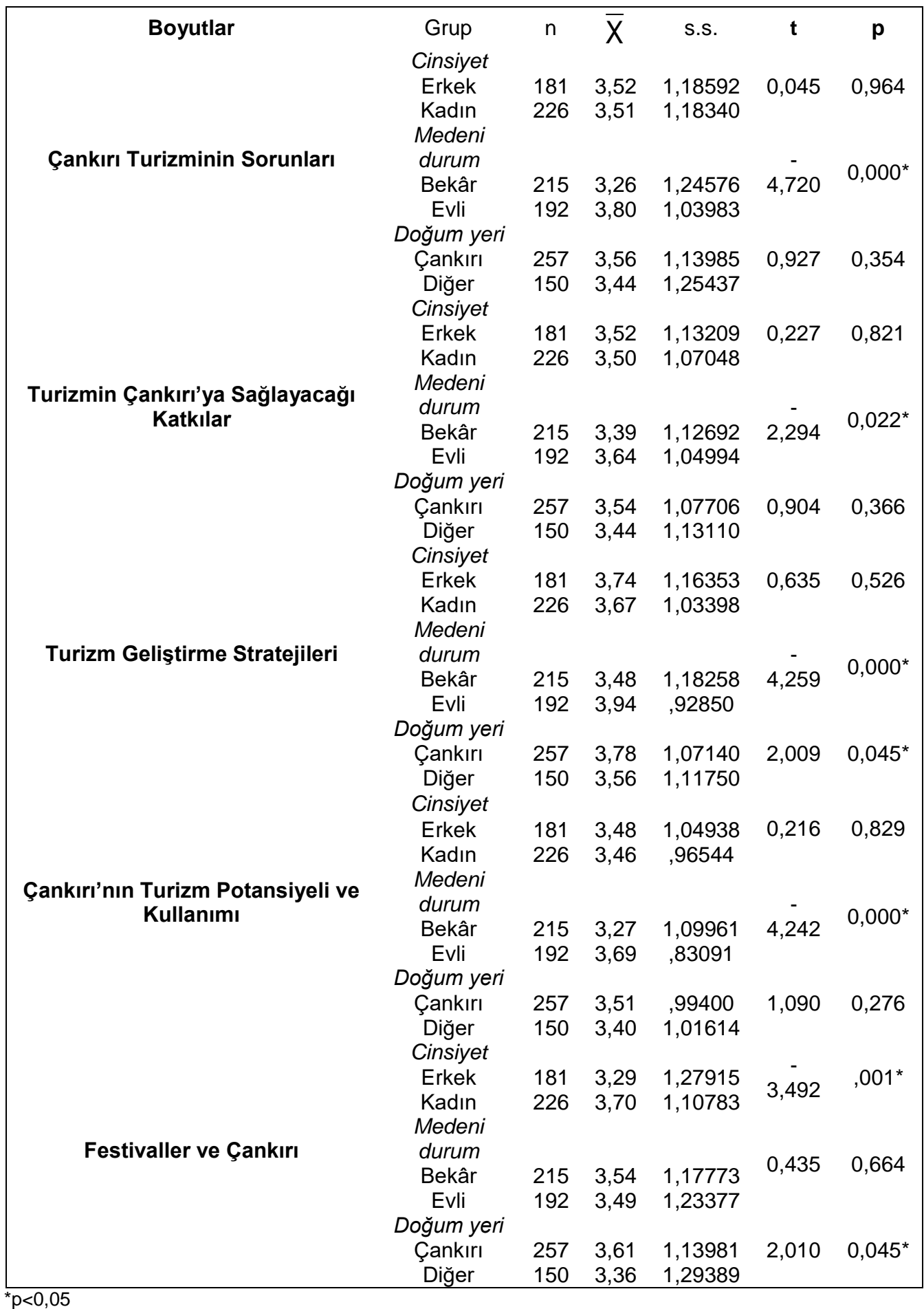

Tablo 6'da yer alan sonuçlara göre katılımcıların cinsiyet değişkenleri ile Çankırı turizminin sorunları, turizmin Çankırı'ya sağlayacağı katkılar, turizm geliştirme stratejileri, Çankırı'nın turizm potansiyeli ve kullanımı algıları arasında anlamlı farklılık 
görülmezken, festivaller ve Çankırı boyutunda ise anlamlı bir farklılık $(p=, 001<0,05)$ tespit edilmiştir.

Katılımcıların medeni durum değişkenleri ile turizm algıları açısından Çankırı turizminin sorunları $(p=, 000<0,05)$, turizmin Çankırı'ya sağlayacağı katkılar $(p=, 022<0,05)$, turizm geliştirme stratejileri $(p=, 000<0,05)$, Çankırı'nın turizm potansiyeli ve kullanımı $(p=, 000<0,05)$ boyutları arasında anlamlı bir farklılık görülürken festivaller ve Çankırı boyutunda anlamlı bir farklılık görülmemiştir.

Katılımcıların doğum yeri değişkenleriyle turizm geliştirme stratejileri $(p=, 045<0,05)$ ile festivaller ve Çankırı boyutları arasında $(p=, 045<0,05)$ anlamlı bir farklılık bulunmuştur. Bu sonuçlara göre "H1. Katılımcıların demografik özellikleri ve Çankırı turizmine yönelik görüşleri arasında bir farklılık vardır." hipotezi kısmen doğrulanmıştır.

Tablo 7: Yerel Halkın Çankırı'da İkamet Sürelerine Göre Çankırı Turizmi Algısına Yönelik One-Way Anova Analizi

\begin{tabular}{|c|c|c|c|c|c|c|c|}
\hline Boyutlar & Grup & $\mathbf{n}$ & $\bar{X}$ & s.s. & $\mathbf{F}$ & p & Tukey \\
\hline \multirow{6}{*}{$\begin{array}{c}\text { Çankırı Turizminin } \\
\text { Sorunları }\end{array}$} & a-1 yıldan az & 17 & 2,84 & 1,62069 & \multirow{6}{*}{7,238} & \multirow{6}{*}{0,000} & \\
\hline & $\mathrm{b}-1-5 \mathrm{yıl}$ arası & 72 & 3,25 & 1,33125 & & & $\mathrm{a}-\mathrm{c}$ \\
\hline & $\mathrm{c}-6-11$ yıl arası & 72 & 4,10 & 0,89132 & & & 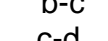 \\
\hline & $\mathrm{d}-12-17 \mathrm{yll}$ arası & 74 & 3,50 & 1,11066 & & & \\
\hline & e-18 yıl ve üzeri & 172 & 3,45 & 1,12330 & & & $c-e$ \\
\hline & a-1 yildan az & 17 & 3,86 & 0,92089 & & & $a-b$ \\
\hline \multirow{5}{*}{$\begin{array}{l}\text { Turizmin Çankırı'ya } \\
\text { Sağlayacağı Katkılar }\end{array}$} & b-1-5 yıl arası & 72 & 3,02 & 1,18589 & \multirow{5}{*}{5,369} & \multirow{5}{*}{0,000} & $b-c$ \\
\hline & c-6-11 yıl arası & 72 & 3,62 & 0,90435 & & & $b-d$ \\
\hline & $\mathrm{d}-12-17$ yıl arası & 74 & 3,76 & 1,01664 & & & $b-e$ \\
\hline & e-18 yıl ve üzeri & 172 & 3,52 & 1,12617 & & & \\
\hline & a-1 yildan az & 17 & 2,96 & 1,30108 & & & $a-d$ \\
\hline \multirow{4}{*}{$\begin{array}{l}\text { Turizm Geliştirme } \\
\text { Stratejileri }\end{array}$} & b-1-5 yıl arası & 72 & 3,24 & 1,18444 & & & $a-e$ \\
\hline & $\mathrm{c}-6-11$ yıl arası & 72 & 3,74 & 0,92812 & \multirow[t]{3}{*}{7,582} & \multirow[t]{3}{*}{0,000} & $b-c$ \\
\hline & $\mathrm{d}-12-17$ yıl arası & 74 & 4,00 & 0,81181 & & & $b-d$ \\
\hline & e-18 yıl ve üzeri & 172 & 3,82 & 1,12066 & & & $b-e$ \\
\hline \multirow{6}{*}{$\begin{array}{c}\text { Çankırı'nın Turizm } \\
\text { Potansiyeli ve } \\
\text { Kullanımı }\end{array}$} & a-1 yıldan az & 17 & 3,02 & 1,16553 & \multirow{6}{*}{9,029} & \multirow{6}{*}{0,000} & $a-c$ \\
\hline & b-1-5 yıl arası & 72 & 3,00 & 0,93256 & & & $a-d$ \\
\hline & c-6-11 yıl arası & 72 & 3,76 & 0,73145 & & & $b-c$ \\
\hline & $\mathrm{d}-12-17$ yıl arası & 74 & 3,81 & 0,92789 & & & $b-d$ \\
\hline & e-18 yıl ve üzeri & 172 & 3,44 & 1,05417 & & & $b-e$ \\
\hline & a-1 yildan az & 17 & 3,64 & 1,32009 & & & \\
\hline \multirow{4}{*}{ Festivaller ve Çankırı } & b-1-5 yıl arası & 72 & 3,51 & 0,91533 & \multirow{4}{*}{4,914} & \multirow{4}{*}{0,001} & \multirow{4}{*}{$c-e$} \\
\hline & $\mathrm{c}-6-11 \mathrm{yll}$ arası & 72 & 3,98 & 0,99990 & & & \\
\hline & $\mathrm{d}-12-17 \mathrm{yll}$ arası & 74 & 3,62 & 1,20163 & & & \\
\hline & e-18 yıl ve üzeri & 172 & 3,27 & 1,31718 & & & \\
\hline
\end{tabular}

Tablo 7'de katıımcıların Çankırı turizmine yönelik görüşleri ile Çankırı'daki ikamet süresi arasında anlamlı farklılığın olup olmadığının tespitine yönelik yapılmış olan test sonuçları yer almaktadır. Katılımcıların Çankırı'da ikamet sürelerine göre bütün boyutlarda farklılıklar $(p<0,05)$ tespit edilmiştir. Farklılıkların kaynağı Tukey testi ile tespit edilmiş ve tablo 7'de gösterilmiştir. Bu sonuçlara göre "H2. Katılımcıların Çankırı'daki ikamet süreleri ile Çankırı turizmine yönelik görüşleri arasında bir farklılık vardır." hipotezi doğrulanmıştır. 
Tablo 8: Katılımcıların Çankırı'nın Doğal ve Kültürel Zenginlikleri Konusundaki Bilgi Düzeyleri ile Çankırı turizmine yönelik görüşlerine Yönelik One-Way Anova Analizi

\begin{tabular}{|c|c|c|c|c|c|c|c|}
\hline Boyutlar & Grup & $\mathbf{n}$ & $\bar{X}$ & s.s. & $\mathbf{F}$ & $\mathbf{p}$ & Tukey \\
\hline \multirow{5}{*}{$\begin{array}{l}\text { Çankırı } \\
\text { Turizminin } \\
\text { Sorunları }\end{array}$} & a-Çok iyi biliyorum & 127 & 3,43 & 1,24546 & \multirow{5}{*}{5,122} & \multirow{5}{*}{0,000} & \multirow{5}{*}{$\begin{array}{l}a-d \\
b-d \\
c-d \\
d-e\end{array}$} \\
\hline & b-Biliyorum & 138 & 3,67 & 0,91219 & & & \\
\hline & c-Biraz Biliyorum & 104 & 3,52 & 1,36895 & & & \\
\hline & d-Çok az biliyorum & 21 & 2,57 & 0,96691 & & & \\
\hline & e-Hiç bilmiyorum & 17 & 4,03 & 1,10480 & & & \\
\hline Turizmin & a-Çok iyi biliyorum & 127 & 3,49 & 1,19438 & \multirow{5}{*}{9,864} & \multirow{5}{*}{0,000} & \\
\hline Çankırı'ya & b-B́iliyorum & 138 & 3,77 & 0,86863 & & & \\
\hline Sağlayacağı & c-Biraz Biliyorum & 104 & 3,42 & 1,12100 & & & \multirow{3}{*}{$\begin{array}{l}c-d \\
d-d\end{array}$} \\
\hline \multirow[t]{2}{*}{ Katkılar } & d-Çok az biliyorum & 21 & 2,25 & 0,98829 & & & \\
\hline & e-Hiç bilmiyorum & 17 & 3,56 & 0,89571 & & & \\
\hline \multirow{5}{*}{$\begin{array}{c}\text { Turizm } \\
\text { Geliştirme } \\
\text { Stratejileri }\end{array}$} & a-Çok iyi biliyorum & 127 & 3,62 & 1,14182 & \multirow{5}{*}{10,188} & \multirow{5}{*}{0,000} & $a-b$ \\
\hline & b-Biliyorum & 138 & 4,11 & 0,66399 & & & $b-c$ \\
\hline & c-Biraz Biliyorum & 104 & 3,43 & 1,25505 & & & $b-d$ \\
\hline & d-Çok az biliyorum & 21 & 2,98 & 1,08257 & & & $b-e$ \\
\hline & e-Hiç bilmiyorum & 17 & 3,37 & 1,36363 & & & \\
\hline Çankırı'nın & a-Çok iyi biliyorum & 127 & 3,32 & 1,04725 & \multirow{5}{*}{14,564} & \multirow{5}{*}{0,000} & \\
\hline Turizm & b-Biliyorum & 138 & 3,91 & ,74948 & & & $a-b, a-d$ \\
\hline \multirow{4}{*}{$\begin{array}{c}\text { Potansiyeli ve } \\
\text { Kullanımı }\end{array}$} & c-Biraz Biliyorum & 104 & 3,32 & 1,03523 & & & \\
\hline & d-Çok az biliyorum & 21 & 2,59 & 0,91677 & & & $\begin{array}{ll}c-9 \\
b-e\end{array}$ \\
\hline & e-Hiç bilmiyorum & 17 & 3,00 & 0,93541 & & & $c-d$ \\
\hline & a-Çok iyi biliyorum & 127 & 3,31 & 1,29242 & \multirow{5}{*}{3,946} & \multirow{5}{*}{0,004} & \multirow{5}{*}{$\begin{array}{l}b-d \\
c-d\end{array}$} \\
\hline \multirow{4}{*}{$\begin{array}{c}\text { Festivaller ve } \\
\text { Çankırı }\end{array}$} & b-Biliyorum & 138 & 3,69 & 1,23282 & & & \\
\hline & c-Biraz Biliyorum & 104 & 3,63 & 1,03918 & & & \\
\hline & d-Çok az biliyorum & 21 & 2,83 & 1,11056 & & & \\
\hline & e-Hiç bilmiyorum & 17 & 3,76 & 0,83137 & & & \\
\hline
\end{tabular}

Tablo 8'de katılımcıların Çankırı'nın doğal ve kültürel zenginlikleri konusundaki bilgi düzeyleri ile Çankırı turizmine yönelik görüşleri arasında anlamlı farklılığın olup olmadığını belirlemek amacıyla yapılmış olan One-Way Anova testi sonuçları gösterilmektedir. Katılımcıların Çankırı'nın doğal ve kültürel zenginlikleri konusundaki bilgi düzeyleri ile Çankırı turizmine yönelik görüşleri arasında bütün boyutlarda anlamlı farklılıklar $(p<0,05)$ tespit edilmiştir. Farklılıkların kaynağı Tukey testi ile tespit edilmiş ve tablo 8'de gösterilmiştir. Bu sonuçlara göre "H3. Katılımcıların Çankırı'nın doğal ve kültürel zenginlikleri konusundaki bilgi düzeyleri ile Çankırı turizmine yönelik görüşleri arasında bir farkıılık vardır." hipotezi doğrulanmıştır.

Tablo 9: Katılımcılara Göre Çankırı'da Ağırlık Verilmesi Gereken Turizm Türleri*

\begin{tabular}{|c|c|c|c|c|c|}
\hline \multicolumn{6}{|c|}{ Çankırı'da ağırlık verilmesi gereken turizm türleri } \\
\hline & $\mathbf{n}$ & $\%$ & & $\mathbf{n}$ & $\%$ \\
\hline Mağara turizmi & 244 & 60 & Eko-turizm & 88 & 21,6 \\
\hline Kış turizmi & 242 & 59,5 & Av turizmi & 63 & 15,5 \\
\hline Dağ turizmi & 224 & 55 & İnanç Turizmi & 56 & 13,8 \\
\hline Yayla turizmi & 171 & 42 & Kuş gözlemciliği & 32 & 7,9 \\
\hline Kültür turizmi & 161 & 39,6 & Kongre Turizmi & 29 & 7,1 \\
\hline Kamp-karavan turizmi & 98 & 24,1 & Diğer & 26 & 6,4 \\
\hline
\end{tabular}


Tablo 9'daki sonuçlar, Çankırı da ikamet eden katılımcıların büyük bir çoğunluğunun Çankırı'da öncelikle mağara (\%60) ve kış turizmine $(\% 59,5)$ ağırık verilmesi gerektiğine inandığına işaret etmektedir. Araştırma bulguları Çankırı'da ikamet eden yerel halkın kentin turistik arz potansiyeline yönelik bilgi düzeyinin yüksek olduğunu ve şehir merkezine nispeten uzak konumdaki alanları ziyaret ettiklerini ortaya koymuştur.

Literatürde yer alan araştırmalarda (Kuvan ve Akan, 2005; Doğan ve Üngüren, 2012; Solmaz, 2014; Boğan ve Sarışık, 2016; Gündüz, 2018) yerel halkın turizmin ekonomik fayda ve olumlu yönde sosyokültürel değişimler sağlaması gerekçesiyle turizm gelişimine olumlu desteğin olduğu saptanmıştır. Araştırmadan elde edilen bulgular neticesinde de literatürdeki çalışmalara paralel olarak, yerel halkın turizmden beklediği en önemli etkilerden birinin ekonomik gelişim etkisi olduğu görülmüştür.

\section{Tartışma}

Son yıllarda yaşanan gelişmeler ışığında turistik talep yapısı deniz, kum, güneş üçlemesinden sıyrılmış, turistler alternatif arayışlara yönelmiştir. Turistik talep yapısında meydana gelen değişimlere paralel olarak, önemli turistik potansiyele ve alternatif çekiciliklere sahip olan destinasyonların bu gelişmelerden etkilenmesi kaçınılmazdır. Turizm gelişimi, yerel halkın hayatını ekonomik, sosyokültürel ve çevresel yönden etkilemektedir. Söz konusu etkiler olumlu olduğu kadar olumsuzluklar da içermekte olup yerel halkın turizme karşı tutumunu belirlemektedir. Turizm sisteminin düzgün işleyişi ve yerel halk ile turistler arasında karşılıklı faydaya dayalı bir ilişki kurulması, ev sahiplerinin "istekli ortaklar" olmalarına bağlıdır (Kuvan ve Akan, 2005).

Çankırı'nın turizm potansiyeli ve kullanımına yönelik yapılan literatür taraması (Kuter, 2007; Tuna, 2010; Pekin Timur, Orhan ve Aksüt, 2014; Öztürk, 2017), Çankırı'nın zengin bir turizm potansiyeline sahip önemli bir destinasyon olduğuna işaret etmektedir. Doğal, tarihi ve kültürel değerleri ile önemli turizm potansiyeline sahip Çankırı kenti; kültür, sağlık, tarih ve doğa turizmine yönelik artan talep neticesinde geçmiş dönemlerden çok daha fazla ziyaretçi çekmektedir. Ancak Kuter (2007), Çankırı kenti ve yakın çevresinde bulunan bu kaynakların bir kısmının yeterli tanıtım yapılamadığı, bir kısmının ise gerekli turizm yatırımının yapılamaması gibi nedenlerle gelişme gösteremediği, dolayısıyla turizm anlamında tanımlı mekânlar haline dönüşemediğini belirtmiştir. Benzer şekilde Timur, Orhan ve Aksüt (2014), Çankırı ilinin doğal ve kültürel özellikleri ile turizm ve rekreasyon bağlamında değerlendirilebilecek birçok özelliğinin olmasına karşın Ilgaz Dağı'ndaki tesisler ile sadece dağ ve kış turizmi ile anıldığını ifade etmişlerdir. Dede (2011), Çankırı Tuz Mağarası'nın, insan sağlığı üzerindeki tedavi edici özelliklerinin saptanması amacı ile hazırladığı çalışmasında mağaradaki sıcaklık değerlerinin uygun sıcaklık aralığında olduğu belirtilmiştir. Tuna (2010), mağaranın speleoterapi tedavi için uygun ortama sahip olması ve Tuz Mağarası'nın güneyinde bulunan tuzlu termal su kaynağının varlığı sağlık turizmi için önemli fırsatlar yarattığını ancak Çankırı'nın turizmde kendinden yeterince söz ettiremediğini ifade etmiştir.

Yerel halkın bölge turizmine yönelik bakış açısı ve turizm farkındalığına yönelik yapılan bu araştırmada uygulanan anket çalışması ve istatistiki analizler sonucunda elde edilen temel bulgular, katılımcıların yaşadıkları bölgenin turizmine yönelik farkındalıklarının yüksek olduğunu, turizmin Çankırı ekonomisine önemli katkılar sağlayacağını ve istihdam imkânını artıracağını düşündüklerine işaret etmektedir. Bu sonuç literatürdeki (Gündüz, 2018; Boğan ve Sarışık, 2016; Doğan ve Üngüren, 2012; 
Solmaz, 2014) çalışmaların sonuçları ile paralellik göstermektedir. Bununla birlikte katılımcılar Çankırı'da turizme gereken önemin verilmediğini düşünmektedirler.

\section{Sonuç ve Öneriler}

Ankara, Karabük, Kastamonu gibi merkezlere yakınlığından dolayı yurtiçi tur güzergâhlarına dâhil edilebilecek konumu, sahip olduğu zengin tarihi değerlere rağmen tarihi eserlerin bakımsızlığı ve proje eksikliği, ulaşım problemleri ve konaklama tesislerinin azlığı gibi nedenlerden dolayı Çankırı turizmde kendinden yeterince söz ettirememiştir (Tuna, 2010: 234). Karadeniz Bölgesi geçiş güzergâhında yer almasına rağmen, özellikle tanıtım eksiklikleri nedeniyle, kente gelen ziyaretçiler çoğunlukla günübirlik ziyaretler gerçekleştirmektedir. Bu noktada yerel yönetimlerin, sivil toplum kuruluşlarının, üniversite ve kamu kuruluşlarının daha etkin çalışma içine girerek bölgelerindeki turistik arz potansiyeli envanterini çıkarmaları ve bunların tanıtımında etkin rol oynamaları gerekmektedir. Seyahat acenteleri ile il genelinde yapılabilecek aktiviteler ve turlar hakkında bilgi paylaşılarak bu turların düzenlenmesine yönelik çalışmalar yapılmalıdır.

Turizm faaliyetleri pek çok toplumda erklerce, festivaller, doğal ve kültürel cazibe merkezleri ve açık hava eğlence fırsatları gibi yaşam kalitesini artırabilecek unsurların yanı sıra özellikle oluşturacağı istihdam fırsatları ile potansiyel bir ekonomik temel olarak algılanabilmektedir. Ancak turistik bir ürün olarak destinasyonun sürdürülebilir gelişiminin sağlanması için yönetici ve planlayıcıların, turizmin sadece ekonomik boyutunu değil, tüm paydaşların beklentilerini anlamaya çalışan bir anlayış ortaya koyması gerekmektedir. Bu paydaşlar arasında yerel halk önemli bir konuma sahiptir. Zira bir destinasyonda turizmin gelişmesi ile yerel halkın turizm desteklemesi arasında pozitif yönlü bir ilişki söz konusudur. Yerel halkın turizmi kabullenip, içselleştirmesi ve katılım göstermesi bölgedeki turizm gelişiminde anahtar bir rol üstlenmektedir. Bu noktada yörede turizm gelişim sürecinde yerel halkın turizm bilincinin ve farkındalığının artırılmasına yönelik çalışmalar yapılmalıdır. Ayrıca yerel halkın il merkezi dışında kalan turistik alanları ziyaret edebilmesi için ulaşım alt yapısının geliştirilmesi, toplu taşıma hizmetlerinin yaygınlaştırılması önerilmektedir.

Bir destinasyonun tanıtımı, gelişimi ve cazibe merkezi haline gelmesinde önemli rol üstlenen, bir turist çekim unsuru olarak değerlendirilen festivaller, spor olayları, kültürel olaylar, fuarlar, sergiler gibi özel etkinlikler günümüzde turizm talebini arttırmada kullanılan en önemli araçlardan biridir. Festivaller, turizm kaynaklı elde edilen gelir, bölgesel istihdam ve destinasyona yönelik yapılan olumlu ağızdan ağıza reklam davranışı üzerinde olumlu etkiye sahiptir. Çankırı'da düzenlenecek festivallerin etkili bir şekilde tanıtımının yapılması, yöresel ürünlerin standart hale getirilerek satışının sağlanması, gelecek yıllarda il ekonomisinde pozitif etki yaratacaktır.

Turizm gelişimi ister kırsal ister kentsel alanlarda olsun, bir destinasyonun ekonomisini canlandırmanın etkili bir yolu olarak kabul edilmektedir. Bununla birlikte, turizm endüstrisinin gelişimi ve sürekliliği büyük ölçüde yerel halkın iyi niyetine, katılımına ve desteğine dayanmaktadır. Bu nedenle turizm, yerel halkın ihtiyaç ve isteklerine göre geliştirilmelidir. Yerel halkın turizm etkileri hakkındaki algılarını ve turizm gelişimine yönelik tutumlarını anlamak, her türlü turizm gelişiminin başarısı ve sürdürülebilirliği için esastır. Destinasyonun yapısı ve koşullar zamanla değişebileceğinden, yerel halkın turizm gelişiminin etkileriyle ilgili algıları, katılımları ve turizme olan destekleri sürekli izlenip yönetilmelidir. 
Bu çalışmada sadece Çankırı'da ikamet eden yerel halkın görüşleri alınmıştır. Çalışmanın en önemli sınırıı̆̆ı örneklem sayısıyla alakalıdır. Araştırmada 407 anket değerlendirmeye alınmıştır. Daha fazla örneklem ile yapılabilecek bir anket ile daha farklı sonuçlar elde edilebilecektir. Illerde yapılması muhtemel çalışmalarda Çankırı'yı ziyaret eden turistlerin de görüşlerinin alınması daha güçlü çıkarımlar yapılmasına imkân verebilir. Ayrıca bu çalışmanın gelecek yıllarda farklı örneklemler ile tekrarlanmasıyla farklı dönemlerde yerel halkın Çankırı turizmine yönelik bakış açılarında değişiklik olup olmadığı araştırılabilir. Tutumların belirlenmesi, yerel halk ile ilgili paydaşların muhtemel çatışma alanlarını tespit etmek ve bunları çözmek için gerekli önlemleri almak açısından yararlı olabilecektir.

\section{Kaynakça}

Akyol, C., Zengin , B., Akkaşoğlu, S. ve Ulema, Ş. (2020). Yerel YöneticilerinBölge Turizmine Yönelik Düşünceleri Üzerine Bir Araştırma:Artvin -Arhavi Örneği. Eskişehir Osmangazi Üniversitesi İ̈BF Dergisi, 15(2), 743-764.

Alaeddinoğlu, F. (2007). Van Halkının Turisti ve Turizmi Algılama Şekli. Coğrafi Bilimler Dergisi, 5(1), 1-16.

Alaeddinoğlu, F. (2008). Sivas Kentinde Halkın Turiste ve Turizme Bakışı. Uluslararası İnsan Bilimleri Dergisi, 5(2), 1-24.

Andriotis, K. ve Vaughan, R. D. (2003). Urban Residents' Attitudes toward Tourism Development: The Case of Crete. Journal of Travel Research, 42(2), 172-185.

Bakır, A. (2018). Türk-İslam Dünyasının Geç Dönemlerinde Tıp Kültürü Ve Çalışmaları. Selçuklu Medeniyeti Araştırmaları Dergisi(3), 11-61.

Berber, Ş. (2003). Sosyal Değişme Katalizörü Olarak Turizm Ve Etkileri. Selçuk Üniversitesi Sosyal Bilimler Enstitüsü Dergisi(9), 205-221.

Bestard, A. B. ve Nadal, J. R. (2007). Modelling environmental attitudes toward tourism. Tourism Management, 28(3), 688-695.

Boğan, E. ve Sarış̧ı, M. (2016). Yerel Halkın Turizm Faaliyetlerine Yönelik Görüş ve Algılamalarının Belirlenmesi Üzerine Alanya'da Bir Araştırma. Kastamonu Üniversitesi İktisadi ve İdari Bilimler Fakültesi Dergisi, 12(2), 325-342.

Chen, J. S. (2001). Assessing and Visualizing Tourism Impacts From Urban Residents' Perspectives. Journal of Hospitality and Tourism Research, 25(3), 235-250.

Choi, H.-S. C. ve Sarıkaya, E. (2005). Measuring Residents' Attitude toward Sustainable Tourism: Development of Sustainable Tourism Attitude Scale. Journal of Travel Research(43), 380-394.

Çiçek, D. ve Sarı, Y. (2018). Yerel Halkın Turizme Olan Desteği: Türkiye'deki Sakin Şehirler Üzerine Bir Araştırma. Anatolia: Turizm Araştırmaları Dergisi, 29(2), 185-196.

Dede, Z. (2011). Çankırı Tuz Mağaralarının Tıbbi Jeoloji Açısından Değerlendirilmesi. Niğde: Niğde Üniversitesi Fen Bilimleri Enstitüsü.

Deniz, D., Küçük, B., Cansız, Ş., Akgün , L. ve İşleyen, T. (2014). Ortaöğretim Matematik Öğretmeni Adaylarının Üstbiliş Farkındalıklarının Bazı Değişkenler Açısından İncelenmesi. Kastamonu Eğitim Dergisi, 22(1), 305-320.

Dilekçi, Ü. ve Sezgin Nartgün, Ş. (2020). Öğretmenlerin Algıladıkları Uyumsal Performans Ölçeği'nin Türk Kültürüne Uyarlanması: Geçerlik-Güvenirlik ve Betimsel Analiz. Hacettepe Üniversitesi Eğitim Fakültesi Dergisi, 35(2), 448-465.

Doğan, H. ve Üngüren, E. (2012). Yerel Halkın Isparta Turizmine Yönelik Görüşleri Üzerine Bir Araştırma. Süleyman Demirel Üniversitesi İktisadi Ve İdari Bilimler Fakültesi Dergisi, 17(1), 103-122.

Doğdubay, M. ve Göker, G. (2018). Alternatif Birer Çekicilik Unsuru Olarak Halo Terapi ve Speleo Terapi (Çankırı Potansiyelinin İncelenmesi). B. Eryılmaz, K. Özlü, Y. 
B. Keskin, ve C. Yücetürk içinde, Sosyal Bilimlerde Güncel Akademik Çalışmalar (s. 245-258). Ankara: Gece Kitaplığı.

Ercan, F. (2019). Karadeniz Ereğli İlçesinde Yerel Halkın Turizmin Gelişimine Yönelik Tutum ve Algılarını Belirlemeye Yönelik Bir Araştırma. Uluslararası Yönetim İktisat ve İşletme Dergisi, 15(2), 612-628.

Gündüz, S. (2018). Yerel Halkın Turizm Algısını Belirlemeye Yönelik Alternatif Bir Ölçek Geliştirme: Karataş Destinasyonu Örneği. Journal of Yasar University, 13(52), 343-357.

Güneş, E. ve Alagöz, G. (2018). Yerel Halkın Turizm Algısı: Erzincan'da Bir Araştırrma. Iğdır Üniversitesi Sosyal Bilimler Dergisi(15), 409-442.

Hançer, Ş. ve Mancı, A. R. (2017). Yerel Halkın Turizme Bakış Açısının Belirlenmesi Üzerine Bir Araştırma: Diyarbakır Örneği. Journal of Tourism and Gastronomy Studies, 5(4), 70-91.

Harrill, R. (2004). Residents' Attitudes toward Tourism Development: A Literature Review with Implications for Tourism Planning. Journal of Planning Literature, 18(3), 251-266.

http://bolge9.ormansu.gov.tr/9bolge/planlar/cankiri_il_tabiat_turizm_master_plani.pdf [Erişim Tarihi: 18 Temmuz 2019].

http://www.cankiri.gov.tr/sayilarla-cankiri-1 [Erişim Tarihi: 18 Temmuz 2019].

https://www.kulturportali.gov.tr/turkiye/cankiri/gezilecekyer/haci-murad-i-veli-camii-veturbesi [Erişim Tarihi: 19 Temmuz 2019].

https://www.kulturportali.gov.tr/turkiye/cankiri/gezilecekyer/tas-mescit-cemalddinferruh-dar-ul-hadis [Erişim Tarihi: 19 Temmuz 2019].

İbiş, R. (2014). Çankırı Kültür Envanteri. Bölge Tarihi. Çankırı: T.C. Çankırı Valiliği İı Kültür Ve Turizm Müdürlüğü Müze Müdürlüğü.

Kahraman, N. ve Türkay, O. (2014). Turizm ve Çevre (6 b.). Ankara: Detay Yayıncılık.

Kuter, N. (2007). Çankırı Kenti Ve Çevresinin Turizm Açısından Değerlendirilmesi. ZKÜ Bartın Orman Fakültesi Dergisi, 9(11), 71-77.

Kuvan, Y. ve Akan, P. (2005). Residents' attitudes toward general and forest-related impacts of tourism: the case of Belek, Antalya. Tourism Management, 26(5), 691-706.

Lee, T. J., Li, J. ve Kim, H. K. (2007). Community Residents' Perceptions and Attitudes Towards Heritage Tourism in a Historic City. Tourism and Hospitality Planning and Development, 4(2), 91-109.

Mansuroğlu, Z. (2006). Turizm Gelişmelerine Yerel Halkın Yaklaşımlarının Belirlenmesi: Akseki/Antalya Örneği. Aknezin Üniversitesi Ziraat Fakültesi Dergisi 2006, 19(1), 35-46.

Meriç, S. ve Erten, Ş. (2020). Üniversite Öğrencilerinin Turizm Algısı: Van Yüzüncü Yıl Üniversitesi Örneği. Kahramanmaraş Sütçü İmam Üniversitesi Sosyal Bilimler Dergisi, 17(1), 420-440.

Meydan, C. H. ve Şeşen, H. (2011). Yapısal Eşitlik Modellemesi AMOS Uygulamaları. Ankara: Detay Yayıncılık.

Nunkoo, R. ve Ramkissoon, H. (2007). Residents' perceptions of the socio-cultural impact of tourism in Mauritius. Anatolia: An Inernational Journal of Tourism and Hospitality Research, 18(1), 138-145.

Nunkoo, R. ve Haywantee , R. (2011). Developing a community support model for tourism. Annals of Tourism Research, 38(3), 964-988.

Oğuzbalaban, G. (2017). Türkiye'de Yerel Halkın Turizme Ve Turizmin Etkilerine Yönelik Algı ve Tutumlarına İlişkin Yazın Taraması. Uluslararası Sosyal Araştırmalar Dergisi, 10(51), 1321-1330.

Öner, S. ve Aydoğdu, A. (2019). Yerel Halkın Gastronomi Turizmine Karşı Tutum ve Bilgi Düzeyi: Kastamonu İçin Çıkarımsal Bir Analiz. Journal of Tourism and Gastronomy Studies , 7(1), 535-560. 
Özdemir, M. A. ve Kervankıran, İ. (2011). Turizm Ve Turizmin Etkileri Konusunda Yerel Halkın Yaklaşımlarının Belirlenmesi: Afyonkarahisar Örneği. Marmara Coğrafya Dergisi(24), 1-25.

Öztürk, Y. (2017). Rekreasyonel Faaliyetlerin Algılanan Kalitesinin Destinasyon İmajına Etkisi: Ilgaz Dağı Milli Parkı Örneği. Yayımlanmamış Doktora Tezi, Ankara: Gazi Üniversitesi Sosyal Bilimler Enstitüsü.

Öztürk, A. B., Özer, Ö. ve Çaliskan, U. (2015). The Relationship between Local Residents' Perceptions of Tourism and Their Happiness: A Case of Kusadasi, Turkey. Tourism Review, 70(3), 232-242.

Sandal , E. K. ve Karademir, N. (2016). Kahramanmaraş'ta Halkın Turizme Bakışı. Türk Coğrafya Dergisi(66), 63-70.

Sert, A. N. (2019). Sürdürülebilir Turizm Gelişiminde Turizmin Yerel Halk Tarafından Algılanan Etkilerinin, Toplum Katılımının ve Turizm Gelişimine Desteğin Rolü: Beypazarı Örneği. Balıkesir Üniversitesi Sosyal Bilimler Enstitüsü Dergisi, 22(42), 407-428.

Solmaz, C. (2014). Yerel Halkın Bölge Turizmine Bakış Açısının Belirlenmesi: Burdur'da Bir Araştırma. Mehmet Akif Ersoy Üniversitesi Sosyal Bilimler Enstitüsü Dergisi, 6(10), 91-105.

Şencan, H. (2005). Sosyal ve Davranışsal Ölçümlerde Güvenilirlik ve Geçerlilik. Ankara: Seçkin Yayıncılık.

Şentürk, F. K. ve Toprak , L. S. (30 Kasım - 4 Aralık 2011,). Turizmin Sosyo-Kültürel Etkilerinin Din Görevlilerinin Bakış Açısıyla Değerlendirilmesi. 12. Ulusal Turizm Kongresi , (s. 324-334). Düzce.

Tabachnick, B. G. ve Fidell, L. S. (2013). Using Multivariate Statistics. Allyn and Bacon/Pearson Education.

Timur, U. P., Orhan, M. ve Aksüt, A. (2014). Çankırı Kaya Tuzu Mağarasının ve Yakın Çevresinin Turizm ve Rekreasyonel Amaçlı Kullanımının İrdelenmesi. Ormancılık Dergisi, 10(1), 97-113.

Toprak, L. (2015). Mardin'de Halkın Turizm Algısı. Elektronik Sosyal Bilimler Dergisi, 14(54), 201-218.

Tuna, F. (2010). Çankırı'nın Coğrafi Özelliklerinin Şehirsel Gelişim Potansiyeli Yönünden Değerlendirilmesi. Marmara Coğrafya Dergisi(21), 219-239.

Türkan, O. (2017). Çankırı Şehrinde Üniversite Öğrencilerinin Kentsel Çevre Algısı. Uluslararası Sosyal Araştırmalar Dergisi, 10(53), 409-424.

Ural, A. ve Kılıç, İ. (2013). Bilimlesı Araştırma Süreci Ve SPSS İle Veri Analizi (4. Baskı b.). Ankara: Detay Yayıncılık.
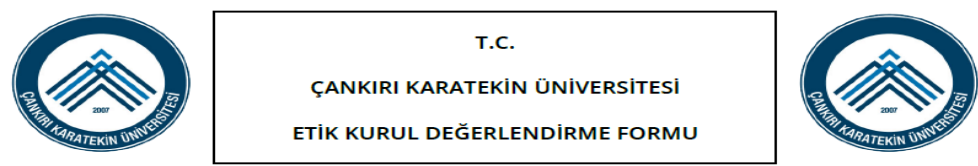

\begin{tabular}{|l|l|}
\hline Toplantı No: & 116 \\
\hline Karar No: & 116 \\
\hline Araştırmanın Yürütücüsü: & Dr. Öğr. Üyesi Yakup ÖZTüRK \\
\hline Araştırmanın Başı̆̆ı: & $\begin{array}{l}\text { Yerel Halkın Turizme Yönelik Görüşlerinin ve Farkındalığının } \\
\text { Belirlenmesi Üzerine Çankırı"da Bir Araştırma }\end{array}$ \\
\hline Kurula Geldiği Tarih: & $4.4 .201915: 21: 29$ \\
\hline Kurulda Incelendiği Tarih: & $4.4 .201916: 19: 23$ \\
\hline Karar Tarihi: & $30.4 .201914: 13: 53$ \\
\hline Kurul Görüşü: & Çalışma Kriterlere Uygundur. \\
\hline
\end{tabular}

SONUÇ:

Kabul. Araştırmanın/Projenin uygulanabilirliği konusunda bilimsel araştırmalar etiği açısından bir sakınca yoktur. 